\title{
Severity of Maternal SARS-CoV-2 Infection in Pregnancy Predicts Neonatal Outcomes
}

\author{
Beril Yasa, MD ${ }^{1}$ Seyma Memur, MD ${ }^{1}$ Dilek Yavuzcan Ozturk, MD ${ }^{1}$ Onur Bagci, MD ${ }^{1}$ \\ Sait Ilker Uslu, MD ${ }^{1}$ Ibrahim Polat, MD² Merih Cetinkaya, MD, PhD ${ }^{1}$ \\ ${ }^{1}$ Neonatology Department, Istanbul Basaksehir Cam and Sakura City \\ Hospital, Istanbul, Turkey \\ 2 Perinatology Department, Istanbul Basaksehir Cam and Sakura City \\ Hospital, Istanbul, Turkey \\ Address for correspondence Beril Yasa, MD, Neonatology \\ Department, Istanbul Basaksehir Cam and Sakura City Hospital, G-434 \\ Street, No. 2L, Basaksehir, Istanbul, Turkey \\ (e-mail: berilyasa@gmail.com).
}

Am J Perinatol 2023;40:688-696.
Abstract
Keywords
- SARS-CoV-2 infection
- pregnancy
- severity of COVID-19 disease
- neonatal outcomes

\section{Key Points}

- SARS-CoV-2 pandemic is a problem for pregnant women.

- Vertical transmission has been shown in limited studies.

- Maternal disease severity may have impact on neonatal outcomes.

The severe acute respiratory syndrome coronavirus 2 (SARSCoV-2) outbreak was first reported in December 2019 from Wuhan and had an enormous global impact. ${ }^{1}$ As of April 2021, more than 140 million cases were infected with SARS-CoV-2 and more than 3 million were died. ${ }^{2}$

A wide range of clinical presentations have been reported with asymptomatic patients at one edge and the catastrophic pneumonia leading to respiratory failure on the other. ${ }^{3}$ Elder

received

May 15, 2021

accepted after revision

June 25, 2021

article published online

July 28, 2021

people and those with comorbidities such as hypertension and diabetes mellitus have worse clinical course. ${ }^{3}$ Younger patients and being female in sex are reported to be associated with improved outcome. ${ }^{4}$ Pregnant patients with SARS-CoV2 infection are at higher risk for hospitalization, mechanical ventilation, intensive care unit admission, and preterm delivery. ${ }^{5}$ In addition, pregnant women infected with SARS-CoV-2 appear to have higher morbidity and mortality

(c) 2021. Thieme. All rights reserved.

Thieme Medical Publishers, Inc., 333 Seventh Avenue, 18th Floor, New York, NY 10001, USA
DOI https://doi.org/ 10.1055/s-0041-1733783. ISSN 0735-1631. 
compared with general population. ${ }^{6,7}$ SARS-CoV-2 infection in pregnancy was found to be associated with preeclampsia, preterm birth, and stillbirth. ${ }^{8}$ Although the majority of SARSCoV-2 infected newborns are asymptomatic or have milder disease, moderate-to-severe symptoms including multiorgan failure and mortality have also been reported in the neonatal population, especially in premature infants. 9,10

Recent data also suggest that pregnant and peripartum women have more severe illness in the second wave of the COVID-19 pandemic than was observed in the first wave. ${ }^{11}$ Severe SARS-CoV-2 infection in pregnancy was reported to be associated with preeclampsia, preterm birth, gestational diabetes, and low birth weight compared with mild infection. ${ }^{8}$ However, to our best of knowledge, no study primarily focused on the effects of the severity of maternal SARS-CoV-2 infections on neonatal morbidities and mortality.

Therefore, the objective of this study is to evaluate the effect of the severity of maternal SARS-CoV-2 infection on neonatal outcomes.

\section{Materials and Methods}

This retrospective study was conducted at Istanbul Basaksehir Cam and Sakura City Hospital between October 2020 and January 2021. The clinical and laboratory data of 40 pregnant women and neonates were evaluated after local ethical committee approval obtained (Istanbul Mehmet Akif Ersoy Thoracic and Cardiovascular Surgery Hospital, approval no. 2021-21). All pregnant women with positive real time reverse transcriptase polymerase chain reaction (RT-PCR) test for SARS-CoV-2 were included in the study.

The maternal disease severity was classified as mild, moderate, or severe according to the clinical presentations of the mother as defined by Kucirka et al.- Table 1 shows the classification system of maternal disease severity.

Maternal clinical and laboratory data, neonatal demographical data, clinical findings, and neonatal morbidities including respiratory distress syndrome (RDS), neonatal sepsis, necrotizing enterocolitis (NEC), intraventricular hemorrhage (IVH), retinopathy of prematurity (ROP), bronchopulmonary dysplasia (BPD), and mortality were all recorded.
Turkish Neonatology Society (TNS) RDS guideline was used for the diagnosis and treatment of RDS. ${ }^{4,12}$ BPD was determined according to 2001 National Institute of Child Health and Human Development consensus statement as requirement for supplemental oxygen for the first 28 days of life and was classified into three groups in terms of BPD severity (mild, moderate, and severe) depending on the duration and level of supplemental oxygen and mechanical ventilatory support at 36 weeks of postmenstrual age. ${ }^{13}$ NEC was diagnosed considering clinical and radiographic findings and was classified according to modified Bell's criteria. ${ }^{14}$ Volpe classification was used for IVH staging. ${ }^{15}$ ROP was classified according to The International Classification of Retinopathy of Prematurity. ${ }^{16}$ Neonatal sepsis was diagnosed according to the criteria of TNS neonatal infections diagnosis and treatment guideline. ${ }^{17}$

Statistical analysis was performed by IBM SPSS 22.0 (IBM SPSS for Windows version 22, Armonk, NY). The consistency of continuous variables to normal distribution was tested by using the Shapiro-Wilk test. Descriptive statistics are given as mean \pm standard deviation, median (minimum-maximum) for continuous variables and $n$ (\%) for categorical variables. Mean values were compared by using one-way ANOVA and Tukey's HSD post hoc analysis tests and categorical values compared by using Fischer's exact tests, $p$-value of less than 0.05 was considered significant.

\section{Results}

A total of 40 pregnant women with a positive RT-PCR test for SARS-CoV-2 were included to the study. In total, 20 (50\%) of 40 pregnant women had mild symptoms, whereas 12 (30\%) had moderate and 8 (20\%) had severe COVID-19 disease. Maternal lymphocyte and platelet count were significantly lower if the mother had severe disease. Maternal fibrinogen, lactate dehydrogenase, Ferritin, C-reactive protein, and Ddimer levels were significantly higher in the presence of moderate or severe maternal disease. One of the mothers with severe disease died within 3 days after admission due to multiorgan failure. Mortality rate for pregnant women infected with SARS-CoV-2 was 2.5\%. - Table 2 shows the maternal data of three groups.

\begin{tabular}{|c|c|c|c|}
\hline Disease severity & Mild & Moderate & Severe \\
\hline Symptoms & $\begin{array}{l}\text { Asymptomatic } \\
\text { or } \\
\text { fever, cough, myalgia } \\
\text { or } \\
\text { loss of taste or smell }\end{array}$ & $\begin{array}{l}\text { Fever }>39^{\circ} \mathrm{C} \\
\text { Dyspnea } \\
\text { Tachypnea }\end{array}$ & $\begin{array}{l}\text { Dyspnea } \\
\text { Tachypnea } \\
\text { Septic shock } \\
\text { Hypotension } \\
\text { Multiorgan failure }\end{array}$ \\
\hline Respiratory difficulty & No & Yes & Yes \\
\hline Computed tomography of chest & Normal & $\begin{array}{l}\text { Lower respiratory tract } \\
\text { infection (atypical pneumonia) }\end{array}$ & $\begin{array}{l}\text { Lower respiratory tract } \\
\text { infection (atypical pneumonia) }\end{array}$ \\
\hline Oxygen saturation at room air & $\geq 93 \%$ & $\geq 93 \%$ & $<93 \%$ \\
\hline $\begin{array}{l}\text { Ventilatory support or } \\
\text { high flow nasal canula }\end{array}$ & No & No & Yes \\
\hline
\end{tabular}




\begin{tabular}{|c|c|c|c|}
\hline & $\begin{array}{l}\text { Mild } \\
(n=20)\end{array}$ & $\begin{array}{l}\text { Moderate } \\
(n=12)\end{array}$ & $\begin{array}{l}\text { Severe } \\
(n=8)\end{array}$ \\
\hline White blood cell count $\left(\times 10^{9}\right.$ cells $\left./ \mathrm{L}\right)$ Mean \pm SD & $10.17 \pm 3.21$ & $8.56 \pm 2.78^{a}$ & $10.61 \pm 10.59^{a}$ \\
\hline $\begin{array}{l}\text { Lymphocyte count }\left(\times 10^{9} \text { cells } / \mathrm{L}\right) \\
\text { Mean } \pm \text { SD }\end{array}$ & $1.43 \pm 0.51$ & $1.31 \pm 0.55$ & $0.86 \pm 0.26^{\mathrm{a}}$ \\
\hline $\begin{array}{l}\text { Platelet count }\left(\times 10^{9} \text { cells } / \mathrm{L}\right) \\
\text { Mean } \pm \mathrm{SD}\end{array}$ & $271.66 \pm 109$ & $224.35 \pm 89.28^{a}$ & $186.87 \pm 76.82^{\mathrm{a}}$ \\
\hline $\begin{array}{l}\text { Lactate dehydrogenase }(\mathrm{U} / \mathrm{L}) \\
\text { Mean } \pm \mathrm{SD}\end{array}$ & $229 \pm 47.8$ & $272 \pm 69.2^{\mathrm{a}}$ & $359 \pm 127^{a}$ \\
\hline $\begin{array}{l}\text { C-reactive protein }(\mathrm{mg} / \mathrm{dL}) \\
\text { Mean } \pm \text { SD }\end{array}$ & $2.7 \pm 0.3$ & $10.3 \pm 0.7^{\mathrm{a}}$ & $10 \pm 0.7^{\mathrm{a}}$ \\
\hline $\begin{array}{l}\text { Fibrinogen }(\mathrm{mg} / \mathrm{dL}) \\
\text { Mean } \pm \mathrm{SD}\end{array}$ & $491 \pm 99$ & $567 \pm 83^{a}$ & $566 \pm 223^{a}$ \\
\hline $\begin{array}{l}\text { Ferritin }(\mu \mathrm{g} / \mathrm{L}) \\
\text { Mean } \pm S D\end{array}$ & $58 \pm 53$ & $99.3 \pm 49^{a}$ & $376 \pm 454^{\mathrm{a}}$ \\
\hline $\begin{array}{l}\text { Prothrombin time (sec) } \\
\text { Mean } \pm \text { SD }\end{array}$ & $7.6 \pm 0.2$ & $8.0 \pm 0.31^{\mathrm{a}}$ & $8.2 \pm 0.5^{\mathrm{a}}$ \\
\hline $\begin{array}{l}\text { Activated partial thromboplastin time (s) } \\
\text { Mean } \pm \text { SD }\end{array}$ & $32.4 \pm 4.5$ & $32.6 \pm 3.7$ & $38.4 \pm 4.5^{\mathrm{a}}$ \\
\hline $\begin{array}{l}\text { International normalized ratio } \\
\text { Mean } \pm \text { SD }\end{array}$ & $0.85 \pm 0.15$ & $0.89 \pm 0.03$ & $0.91 \pm 0.05$ \\
\hline $\begin{array}{l}\text { D-dimer }(\mu \mathrm{g} / \mathrm{mL}) \\
\text { Mean } \pm S D\end{array}$ & $1.32 \pm 0.15$ & $1.99 \pm 1.15^{\mathrm{a}}$ & $2.16 \pm 2.09^{\mathrm{a}}$ \\
\hline $\begin{array}{l}\text { Duration of hospital stay }(\mathrm{d}) \\
\text { median (range) }\end{array}$ & $2(2-7)$ & $2(2-10)$ & $15.5(3-49)$ \\
\hline $\begin{array}{l}\text { Maternal mortality } \\
n(\%)\end{array}$ & 0 & 0 & $1(12.5)$ \\
\hline
\end{tabular}

Abbreviation: SD, standard deviation.

${ }^{\mathrm{a} O n e-w a y ~ a n a l y s i s ~ o f ~ v a r i a n c e, ~} p<0.05$.

The mean gestational age and birth weight of infants were significantly lower in infants born to mothers with either moderate or severe disease. The need of postnatal resuscitation was higher, and Apgar's scores were lower in infants born to mothers with severe SARS-CoV-2 infection. The development of respiratory difficulty was significantly higher in infants born to moderate or severe disease. - Table 3 shows the demographical data of neonates.

About 18 (45\%) of 40 infants were born as preterm birth. Preterm birth rates were higher in the presence of moderate or severe maternal disease. However, $65 \%(n=26)$ of all infants were asymptomatic after birth, and $35 \%(n=14)$ infants developed respiratory difficulty. Out of 14 infants who developed respiratory difficulty, 3 of them were term infants and 11 were preterm. None of the term infants needed mechanical ventilation, but nine preterm infants were mechanically ventilated. The duration of mechanical ventilation and total hospital stay were significantly higher in infants born to mothers with severe disease. There was no difference in terms of morbidities such as neonatal sepsis, PDA, BPD, IVH, or NEC between groups. One of the infants whose mother had severe disease was died. Exclusive breastfeeding rates at discharge for all infants were $80 \%(n=32)$. Neonatal morbidities are also shown in -Table 3.
Neonates born to mothers with severe disease had significantly lower total leucocyte count, but lymphocyte counts were similar with the other groups. Activated partial thromboplastin time and international normalized ratio were found to be significantly higher in infants born to mothers with severe SARS-CoV-2 infection. Laboratory findings of infants are detailed in -Table 4 . All the individual characteristics of neonates are shown in -Table 5.

\section{Discussion}

This retrospective study showed SARS-CoV-2 infection had an adverse impact on neonatal outcomes proportionally with the maternal disease severity including increased prematurity rates, postnatal resuscitation need, prolonged hospital stay, and longer ventilatory support requirement in infants born to mothers with moderate or severe disease.

SARS-CoV-2 is a capsulated, single-stranded RNA virus. Immunological response relies on working immune system. ${ }^{18}$ SARS-CoV-2 mainly transmitted by respiratory droplets and close person-to-person contact. Infected aerosols enter body and infects pulmonary cells via the SARS-CoV-2 receptor angiotensin converting enzyme 2 (ACE2) for spike (S) protein. ${ }^{19}$ Pregnancy is a relatively immune suppressant 


\begin{tabular}{|c|c|c|c|}
\hline $\begin{array}{l}\text { Maternal disease } \\
\text { severity }\end{array}$ & $\begin{array}{l}\text { Mild } \\
(n=20)\end{array}$ & $\begin{array}{l}\text { Moderate } \\
(n=12)\end{array}$ & $\begin{array}{l}\text { Severe } \\
(n=8)\end{array}$ \\
\hline $\begin{array}{l}\text { Gestational age } \\
\text { (wk) }\end{array}$ & $\begin{array}{l}37.8 \pm 3.2 \\
(26-41)\end{array}$ & $\begin{array}{l}35.1 \pm 3.1^{\mathrm{a}} \\
(28-39.4)\end{array}$ & $\begin{array}{l}32.2 \pm 5.8^{\mathrm{a}} \\
(23-38.2)\end{array}$ \\
\hline $\begin{array}{l}\text { Birth weight } \\
\text { (g) }\end{array}$ & $3,123 \pm 758$ & $2,578 \pm 623^{a}$ & $2,268 \pm 1,203^{a}$ \\
\hline Preterm birth, $n(\%)$ & $4(20)$ & $9(75)^{\mathrm{b}}$ & $5(62.5)^{b}$ \\
\hline Postnatal resuscitation need, $n$ (\%) & $1(5)$ & $2(16.6)$ & $6(75)^{\mathrm{b}}$ \\
\hline \multicolumn{4}{|l|}{$\begin{array}{l}\text { Apgar's scores } \\
\text { median (range) }\end{array}$} \\
\hline $1 \mathrm{~min}$ & $8(4-9)$ & $8(3-8)$ & $5(1-8)$ \\
\hline $5 \mathrm{~min}$ & $9(9-10)$ & $9(7-9)$ & $7(3-9)$ \\
\hline $\begin{array}{l}\text { Respiratory difficulty, } \\
n(\%)\end{array}$ & $3(15)$ & $7(58.3)^{b}$ & $5(62.5)^{b}$ \\
\hline \multicolumn{4}{|l|}{ Duration of mechanical } \\
\hline Ventilation (h) & 0 & 0 & $321^{\mathrm{a}}$ \\
\hline Median (range) & $(0-480)$ & $(0-240)$ & $(0-936)$ \\
\hline $\begin{array}{l}\text { Respiratory distress syndrome, } \\
n(\%)\end{array}$ & 0 & 0 & $5(62.5)^{b}$ \\
\hline Endotracheal surfactant, $n$ (\%) & 0 & 0 & $5(62.5)^{b}$ \\
\hline Neonatal sepsis, $n(\%)$ & $3(15)$ & $8(66.7)^{b}$ & $5(62.5)^{b}$ \\
\hline Patent ductus arteriosus, $n$ (\%) & $1(5)$ & $1(8.3)$ & $3(37.5)^{b}$ \\
\hline $\begin{array}{l}\text { Intraventricular hemorrhage } \geq \text { grade } 2 \text {, } \\
n(\%)\end{array}$ & $1(5)$ & $1(8.3)$ & $2(25)^{\mathrm{b}}$ \\
\hline Necrotizing enterocolitis $\geq$ grade 2 , n (\%) & 0 & 0 & $1(12.5)^{\mathrm{b}}$ \\
\hline Bronchopulmonary dysplasia (moderate/severe), $n$ (\%) & 0 & $1(8.3)$ & $2(25)^{\mathrm{b}}$ \\
\hline Mortality, n (\%) & 0 & 0 & $1(12.5)$ \\
\hline Exclusive breast feeding, $n(\%)$ & $18(90)^{\mathrm{b}}$ & $10(83.3)^{\mathrm{b}}$ & $4(50)$ \\
\hline \multicolumn{4}{|l|}{ Duration of hospital stay } \\
\hline Stay (d) & 2 & 7 & $21.5^{\mathrm{a}}$ \\
\hline Median (range) & $(1-68)$ & $(2-57)$ & $(2-76)$ \\
\hline
\end{tabular}

${ }^{a}$ One-way analysis of variance, $p<0.05$.

'Fischer's exact test, $p<0.05$.

status which allows the growth of semiallogeneic fetus and results in an altered immune response to infections. ${ }^{19}$ During pregnancy, T-helper (Th) 1 associated cell-mediated immune response is downregulated, and this results with T-helper 2 dominant humoral response and allows for the immune tolerance to developing fetus. ${ }^{20}$ These immune changes could have impact on maternal SARS-CoV-2 severity. ${ }^{4}$ Th1 mediated cellular immunity plays an important role in lung damage and Th1 associated cytokines such as interleukin-6 has been associated with poor prognosis in SARS-CoV-2 infection. Therefore, it has been sought that Th2 mediated dominant humoral immune response in pregnancy could contribute to mild disease severity. ${ }^{21,22}$ In contrast, it is also hypothesized that pregnant women are in a pro-inflammatory state in the first and third trimester so they could be more susceptible to infection. A national study from United States suggests that pregnant women infected with SARS CoV-2 are more likely develop severe complications com- pared with their reproductive age nonpregnant counterparts. ${ }^{23}$ Another study comparing pregnant to nonpregnant reproductive age women showed no statistically significant difference in rates of intensive care unit admission. ${ }^{24}$ The incidence of SARS-CoV-2 infection severity in pregnant women was reported in different studies as $13.9 \%,{ }^{25} 15 \%{ }^{26}$ and it was similar to what was described in the literature for the nonpregnant women. ${ }^{27}$ In accordance, the incidence of severe SARS-CoV-2 infection was found $20 \%$ in the present study.

The possibility of vertical transmission of SARS-CoV-2 from infected mother to the fetus is still a debate. ${ }^{28}$ ACE2 is the main host receptor for SARS-CoV-2, and ACE2 is expressed in placenta. ${ }^{29}$ Initially most of the studies reported no evidence of vertical transmission. ${ }^{24,30,31}$ Recently, one large study from New York City also reported no vertical transmission. ${ }^{32}$ There also exists little studies defining cases about vertical transmission. Zeng et $\mathrm{al}^{33}$ reported 
Table 4 Laboratory findings of neonates in the study population

\begin{tabular}{|c|c|c|c|}
\hline & $\begin{array}{l}\text { Mild } \\
(n=20)\end{array}$ & $\begin{array}{l}\text { Moderate } \\
(n=12)\end{array}$ & $\begin{array}{l}\text { Severe } \\
(n=8)\end{array}$ \\
\hline $\begin{array}{l}\text { White blood cell count }\left(\times 10^{9} \text { cells } / \mathrm{L}\right) \\
\text { Mean } \pm \text { SD }\end{array}$ & $17.43 \pm 5.58$ & $16.06 \pm 6.94$ & $11.27 \pm 4.2^{\mathrm{a}}$ \\
\hline $\begin{array}{l}\text { Lymphocyte count }\left(\times 10^{9} \text { cells } / \mathrm{L}\right) \\
\text { Mean } \pm \mathrm{SD}\end{array}$ & $4.10 \pm 1.44$ & $4.27 \pm 2.01$ & $4.02 \pm 1.26$ \\
\hline $\begin{array}{l}\text { Platelet count }\left(\times 10^{9} \text { cells } / \mathrm{L}\right) \\
\text { Mean } \pm S D\end{array}$ & $277.2 \pm 74.47$ & $275.41 \pm 67.19$ & $246.50 \pm 99.94$ \\
\hline $\begin{array}{l}\text { C-reactive protein }(\mathrm{mg} / \mathrm{dL}) \\
\text { Mean } \pm \mathrm{SD}\end{array}$ & $1.83 \pm 3.99$ & $0.83 \pm 1.34$ & $0.43 \pm 0.19$ \\
\hline $\begin{array}{l}\text { Fibrinogen }(\mathrm{mg} / \mathrm{dL}) \\
\text { Mean } \pm \text { SD }\end{array}$ & $233.1 \pm 82$ & $189.8 \pm 160$ & $220 \pm 104$ \\
\hline $\begin{array}{l}\text { Prothrombin time (s) } \\
\text { Mean } \pm \text { SD }\end{array}$ & $13.53 \pm 4.67$ & $13.49 \pm 2.31$ & $13.97 \pm 2.52$ \\
\hline $\begin{array}{l}\text { Activated partial thromboplastin time (s) } \\
\text { Mean } \pm \text { SD }\end{array}$ & $38.5 \pm 6.61$ & $46.4 \pm 15.5$ & $51.1 \pm 11.12^{\mathrm{a}}$ \\
\hline $\begin{array}{l}\text { International normalized ratio } \\
\text { Mean } \pm S D\end{array}$ & $1.24 \pm 0.16$ & $1.4 \pm 0.38$ & $1.5 \pm 0.26^{a}$ \\
\hline $\begin{array}{l}\text { D-dimer }(\mu \mathrm{g} / \mathrm{mL}) \\
\text { Mean } \pm S D\end{array}$ & $2.67 \pm 1.92$ & $1.83 \pm 2.46$ & $4.2 \pm 3.13$ \\
\hline
\end{tabular}

Abbreviation: SD, standard deviation.

${ }^{a}$ One-way analysis of variance, $p<0.05$.

documented immunoglobulin $\mathrm{M}$ in neonates born to mothers who had SARS-CoV-2 infection. SARS-CoV-2 RT-PCR test positivity was reported as $5 \%$ in a cohort study reported from United Kingdom ${ }^{34}$ and $1.9 \%$ in National Registry for Surveillance and Epidemiology of Perinatal COVID-19 Infection. ${ }^{35}$ Turkish Neonatal Society and the national Neo-COVID study from Turkey reported the rate of RT-PCR positivity as $3.3 \%{ }^{36,37}$ None of neonates in our study group had positive SARS-CoV-2 RT-PCR test. This may be associated with low patient population and RT-PCR timing in our study.

Maternal disease severity was found to be directly proportional with neonatal outcomes in the present study. The birth weight and gestational age of infants born either moderate or severe maternal disease were significantly lower than those born to mothers with mild disease. Therefore, it may be reasonable to state that rates of prematurity increase with the severity of maternal disease. The total prematurity rate was $45 \%$ in our study. This was similar to the $47 \%$ prematurity rate found in a review. ${ }^{38}$ The national NeoCOVID study reported the prematurity rate as $26.4 \%$, which is lower than that found in our study and this sought to be related with low sample size in our study. ${ }^{37}$

Most of the infants (65\%) were asymptomatic in our study population. However, $35 \%$ of infants $(n=14)$ developed respiratory difficulty and $78.5 \%$ of them were preterm. In consistent with our findings, many papers reported that most of the infants born to mothers with SARS-CoV-2 are asymptomatic. $^{10,39-41}$ The most common symptoms that are reported in the literature were pneumonia, respiratory distress, fever, feeding intolerance, vomiting, and diarrhea. ${ }^{39,41,42}$ Another study from Turkey evaluating epidemiological and clinical characteristics of neonates with community acquired
COVID-19 reported that main complaints and clinical findings in neonates are fever, hypoxemia, cough, tachypnea, poor feeding, and diarrhea. ${ }^{43}$ In our study population, the most common symptom was respiratory difficulty and pneumonia; in contrast with the literature, there were neither fever nor diarrhea were defined in our patients. This may be associated with the patient characteristics.

The infants born to mothers with moderate or severe SARS-CoV-2 infection had increased postnatal resuscitation need, higher respiratory problems, increased ventilatory support requirement, and had longer hospital stay. Only one preterm infant with gestational age of 23 weeks died in the study group whose mother had severe SARS-CoV-2 infection. This may either be associated extreme prematurity or effect of severe maternal disease.

The associations between maternal SARS-CoV-2 infection severity and neonatal characteristics are not well defined. One recent study evaluating the associations reported that women with severe disease had infants with a lower gestational age at delivery; other characteristics of neonates were similar except maternal disease severity was associated with increased risk of neonatal hyperbilirubinemia requiring phototherapy. ${ }^{32}$ Another study reported that women with severe disease had more adverse obstetrical outcomes, including lower gestational age, higher cesarean delivery, and their infants had higher rates of neonatal intensive care unit admission, RDS, and IVH in contrast to controls. ${ }^{44}$ In accordance, this study associated maternal disease severity with decreased gestational age and birth weight. It also reports increased need of postnatal resuscitation, hospital stay, and ventilatory support requirement in the infants born to mothers with severe SARS-CoV-2 infection. 


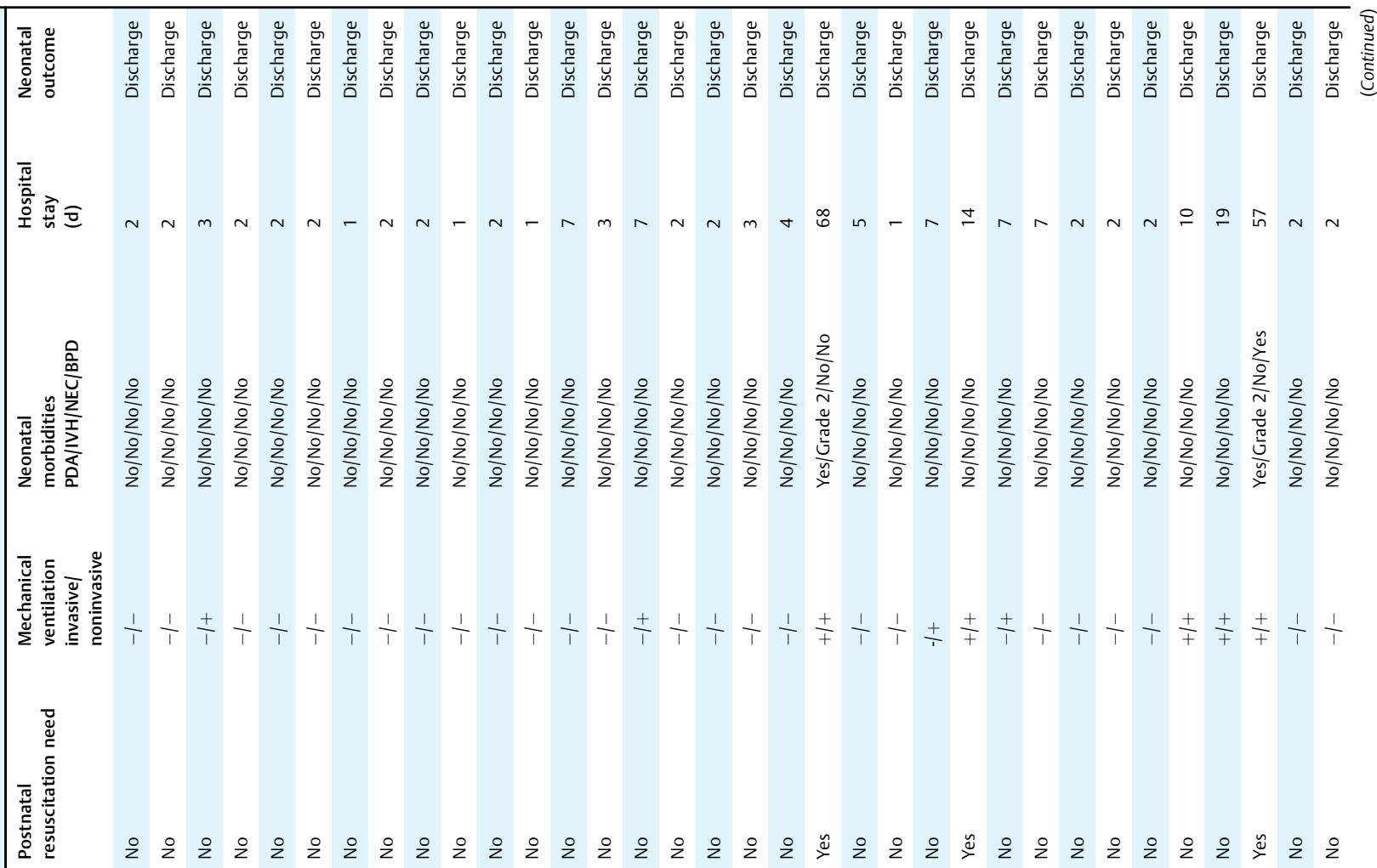

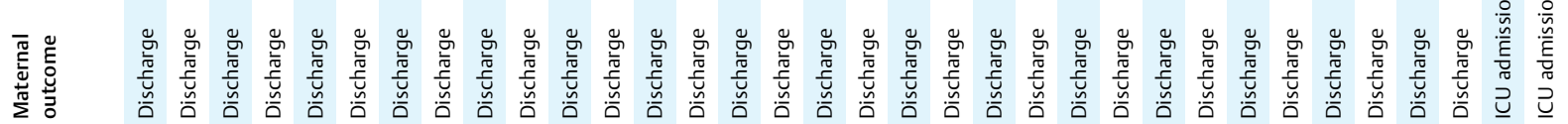

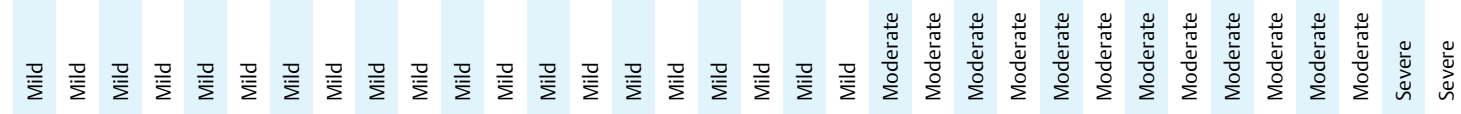

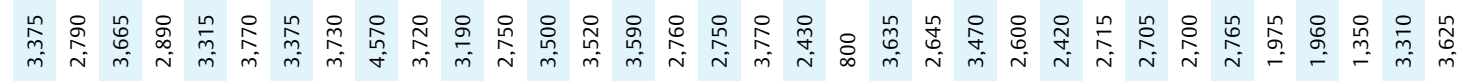

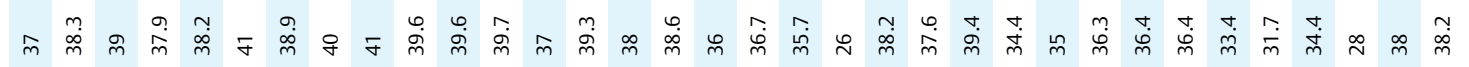

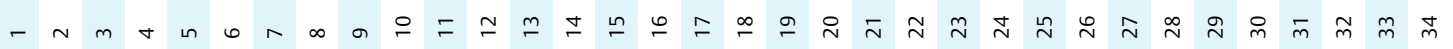




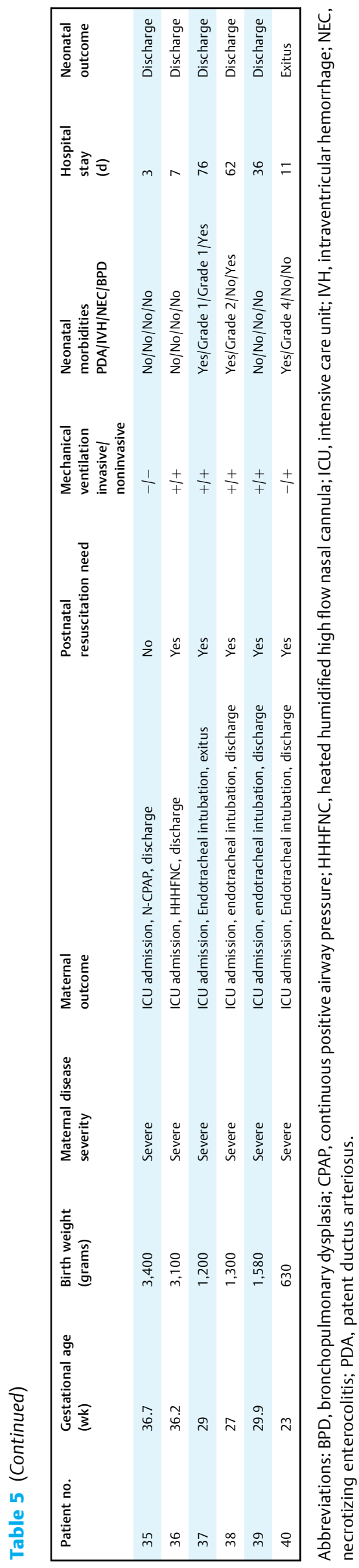

Low sample size, retrospective design, and single referral center experience constitute the main limitations of this study. Also, no placental tissue, amniotic fluid, nor breast milk were tested for SARS-CoV-2 to demonstrate vertical transmission.

In conclusion, to the best of our knowledge, this is one of the exceptional studies evaluating the severity of maternal SARS-CoV-2 infection and its impact on newborn infants. Even no vertical transmission was shown; maternal disease severity had adverse effects on neonatal outcomes. The severity of maternal disease was found to be associated with increased rates of prematurity, requirement of postnatal resuscitation, prolonged hospital stay, and longer ventilatory support.

Even if the newborn infants were not infected with SARSCoV-2, adverse outcomes sought to be related with inflammatory status of mother, increased preterm birth rates, and increased preterm morbidities.

\section{Authors' Contributions}

B.Y. and M.C. conceptualized and designed the study, and they also involved in data acquisition, analysis, and interpretation of data. S.M., D.Y.O., O.B., S.I.U., and I.P. were involved in acquisition and analysis of data. B.Y. drafted the article and M.C. finally approved the submitted version.

Note

Local ethical committee approval was obtained for the study (Istanbul Mehmet Akif Ersoy Thoracic and Cardiovascular Surgery Hospital, approval no: 2021-21). The study was performed in accordance with the Declaration of Helsinki.

\section{Funding}

None.

Conflict of Interest

None declared.

\section{References}

1 Van Keulen BJ, Romijn M, Bondt A, et al. Breastmilk; a source of SARS-CoV-2 specific IgA antibodies. medRxiv 2020. Doi: 10.1101/2020.08.18.20176743

2 World Health Organization. WHO Coronavirus (COVID-19) Dashboard. Accessed 2021 at: https://covid19.who.int

3 Garg S, Kim L, Whitaker M, et al. Hospitalization rates and characteristics of patients hospitalized with laboratory-confirmed coronavirus disease 2019-COVID-NET, 14 States, March 130, 2020. MMWR Morb Mortal Wkly Rep 2020;69(15):458-464

4 Kucirka LM, Norton A, Sheffield JS. Severity of COVID-19 in pregnancy: a review of current evidence. Am J Reprod Immunol 2020;84(05):e13332

5 Lokken EM, Huebner EM, Taylor GG, et al.For the Washington State COVID-19 in Pregnancy Collaborative. Disease severity, pregnancy outcomes and maternal deaths among pregnant patients with SARS-CoV-2 infection in Washington state. Am J Obs Perinatol 2020 https://doi.org/10.1016/j.ajog.2020.12.122

6 Rasmussen SA, Smulian JC, Lednicky JA, Wen TS, Jamieson DJ. Coronavirus Disease 2019 (COVID-19) and pregnancy: what 
obstetricians need to know. Am J Obstet Gynecol 2020;222(05): 415-426

7 Schwartz DA, Graham AL. Potential maternal and infant outcomes from (Wuhan) Coronavirus 2019-nCoV infecting pregnant women: lessons from SARS, MERS, and other human coronavirus infections. Viruses 2020;12(02):1-16

8 Wei SQ Bilodeau-Bertrand M, Liu S, Auger N. The impact of COVID-19 on pregnancy outcomes: a systematic review and meta-analysis. CMAJ 2021;193(16):E540-E548

9 Sankaran D, Nakra N, Cheema R, Blumberg D, Lakshminrusimha S. Perinatal SARS-CoV-2 infection and neonatal COVID-19: a 2021 update. Neoreviews 2021;22(05):e284-e295

10 Sánchez-Luna M, Fernández Colomer B, de Alba Romero C, et al; SENEO COVID-19 Registry Study Group. Neonates born to mothers with COVID-19: data from the Spanish Society of Neonatology Registry. Pediatrics 2021;147(02):e2020015065

11 Kadiwar S, Smith JJ, Ledot S, et al. Were pregnant women more affected by COVID-19 in the second wave of the pandemic? Lancet 2021;397(10284):1539-1540

12 Özkan H, Erdeve Ö, Kutman HGK. Turkish Neonatal Society guideline on the management of respiratory distress syndrome and surfactant treatment. Turk Pediatri Ars 2018;53(Suppl 1):S45-S54

13 Jobe AH, Bancalari E. Bronchopulmonary dysplasia. Am J Respir Crit Care Med 2001;163(07):1723-1729

14 Walsh MC, Kliegman RM. Necrotizing enterocolitis: treatment based onstaging criteria. Pediatr Clin North Am. 1986;33(01): 179-201

15 Volpe JJ. Intracranial hemorrhage: germinal matrix-intraventricular hemorrhage of the premature infant. In: Volpe JJ, ed. Neurology of the Newborn. 5th edition Philadelphia: Elsevier; 2008:517-588

16 International Committee for the Classification of Retinopathy of Prematurity. The International Classification of Retinopathy of Prematurity revisited. Arch Ophthalmol 2005;123(07):991-999

17 Satar M, Arısoy AE, Çelik IH. Turkish Neonatal Society guideline on neonatal infections-diagnosis and treatment. Turk Pediatri Ars 2018;53(Suppl 1):S88-S100

18 Cascella M, Rajnik M, Cuomo A, Dulebohn SC, Di Napoli R. Features, Evaluation and Treatment Coronavirus (COVID-19) (online). Accessed May 27, 2020 at: https://www.ncbi.nlm.nih.gov/pubmed/32150360

19 Wastnedge EAN, Reynolds RM, Van Boeckel SR, Stock SJ, Denison FC, Maybin JA, et al. Pregnancy and COVID-19. Physiol Rev 20211101(01):303-318

20 Reinhard G, Noll A, Schlebusch H, Mallmann P, Ruecker AV. Shifts in the TH1/TH2 balance during human pregnancy correlate with apoptotic changes. Biochem Biophys Res Commun 1998;245(03): 933-938

21 Dashraath P, Wong JLJ, Lim MXK, et al. Coronavirus disease 2019 (COVID-19) pandemic and pregnancy. Am J Obstet Gynecol 2020; 222(06):521-531

22 Gujski M, Humeniuk E, Bojar I. Current state of knowledge about SARS-CoV-2 and COVID-19 disease in pregnant women. Med Sci Monit 2020;26(26):e924725

23 Ellington S, Strid P, Tong VT, et al. Characteristics of women of reproductive age with laboratory-confirmed SARS-CoV-2 infection by pregnancy status - United States, January 22-June 7, 2020. MMWR Morb Mortal Wkly Rep 2020;69(25):769-775

24 Qiancheng X, Jian S, Lingling P, et al; sixth batch of Anhui medical team aiding Wuhan for COVID-19. Coronavirus disease 2019 in pregnancy. Int J Infect Dis 2020;95(95):376-383

25 Breslin N, Baptiste C, Gyamfi-Bannerman C, et al. Coronavirus disease 2019 infection among asymptomatic and symptomatic pregnant women: two weeks of confirmed presentations to an affiliated pair of New York City hospitals. Am J Obstet Gynecol MFM 2020;2(02):100118

26 Pierce-Williams RAM, Burd J, Felder L, et al. Clinical course of severe and critical coronavirus disease 2019 in hospitalized pregnancies: a United States cohort study. Am J Obstet Gynecol MFM 2020;2(03):100134

27 Vintzileos WS, Muscat J, Hoffmann E, et al. Screening all pregnant women admitted to labor and delivery for the virus responsible for coronavirus disease 2019. Am J Obstet Gynecol 2020;223(02): 284-286

28 Kotlyar AM, Grechukhina O, Chen A, et al. Vertical transmission of coronavirus disease 2019: a systematic review and meta-analysis. Am J Obstet Gynecol 2021;224(01):35-53.e3

29 Levy A, Yagil Y, Bursztyn M, Barkalifa R, Scharf S, Yagil C. ACE2 expression and activity are enhanced during pregnancy. Am J Physiol Regul Integr Comp Physiol 2008;295(06):R1953-R1961

30 Liao J, He X, Gong Q, Yang L, Zhou C, Li J. Analysis of vaginal delivery outcomes among pregnant women in Wuhan, China during the COVID-19 pandemic. Int J Gynaecol Obstet 2020;150 (01):53-57

31 Pereira A, Cruz-Melguizo S, Adrien M, Fuentes L, Marin E, PerezMedina T. Clinical course of coronavirus disease-2019 in pregnancy. Acta Obstet Gynecol Scand 2020;99(07):839-847

32 Dumitriu D, Emeruwa UN, Hanft E, et al. Outcomes of neonates born to mothers with severe acute respiratory syndrome coronavirus 2 infection at a large medical center in New York City. JAMA Pediatr 2021;175(02):157-167

33 Zeng H, Xu C, Fan J, et al. Antibodies in infants born to mothers with COVID-19 pneumonia. JAMA 2020;323(18):1848-1849

34 Knight M, Bunch K, Vousden N, et al; UK Obstetric Surveillance System SARS-CoV-2 Infection in Pregnancy Collaborative Group. Characteristics and outcomes of pregnant women admitted to hospital with confirmed SARS-CoV-2 infection in UK: national population based cohort study. BMJ 2020;369:m2107

35 SONPM National Registry for Surveillance and Epidemiology of Perinatal COVID-19 Infection Section on Neonatal-Pernatal Medicine. American Academy of Pediatrics. Accessed 2021 at: https:// my.visme.co/view/ojq9qq8e-npc-19-registry

36 Erdeve Ö, Çetinkaya M, Baş AY, et al. The Turkish Neonatal Society proposal for the management of COVID-19 in the neonatal intensive care unit. Turk Pediatri Ars 2020;55(02):86-92

37 Oncel MY, Akın IM, Kanburoglu MK, et al; Neo-Covid Study Group. A multicenter study on epidemiological and clinical characteristics of 125 newborns born to women infected with COVID-19 by Turkish Neonatal Society. Eur J Pediatr 2021;180(03):733-742

38 Mullins E, Evans D, Viner RM, O'Brien P, Morris E. Coronavirus in pregnancy and delivery: rapid review. Ultrasound Obstet Gynecol 2020;55(05):586-592

39 Zeng L, Xia S, Yuan W, et al. Neonatal early onset infection with SARS-CoV-2 in 33 neonates born to mothers with Covid-19 in Wuhan, China. JAMA Pediatr 2020;174(07):722-725

40 Salvatore CM, Han JY, Acker KP, et al. Neonatal management and outcomes during the COVID-19 pandemic: an observational cohort study. Lancet 2020. Accessed 2020 at: https://doid.org/ 10.1016/52352-4642(20)30235-2

41 Shalish W, Lakshminrusimha S, Manzoni P, Keszler M, Sant'Anna GM. Covid-19 and neonatal respiratory care: current evidence and practical approach. Am J Perinatol 2020;37(08): 780-791

42 Cook J, Harman K, Zoica B, Verma A, D'Silva P, Gupta A. Horizontal transmission of severe acute respiratory syndrome coronavirus 2 to a premature infant: multiple organ injury and association with markers of inflammation. Lancet Child Adolesc Health 2020;4 (07):548-551

43 Kanburoglu MK, Tayman C, Oncel MY, et al. A multicentered study on epidemiologic and clinical characteristics of 37 neonates with community-acquired COVID-19. Pediatr Infect Dis J 2020;39(10): e297-e302

44 Brandt JS, Hill J, Reddy A, et al. Epidemiology of COVID 19 in pregnancy: risk factors and associations with adverse maternal and neonatal outcomes. Am J Obstet Gynecol 2020. Doi: 10.1016/j. ajog.2020.09.043 
